\title{
The Implication of e-WoM Communication on Customer Preference and Purchase Decision of Electronic Gadgets
}

\author{
Budiono Hardjono $\bowtie$, Sugeng A. Riyadi, Diba Aris \\ Faculty of Economics and Business, Binawan University, Jakarta, Indonesia
}

\begin{tabular}{l} 
Info Article \\
\hline History Article: \\
Submitted 17 September 2019 \\
Revised 15 November 2019 \\
Accepted 26 November 2019 \\
\hline Keywords: \\
E-WoM; Customer Preference; \\
Customer Purchase Decision \\
Inter-Personal Ties; Homophily; \\
Source of Credibility.
\end{tabular}

Info Article

Submitted 17 September 2019

Revised 15 November 2019

Accepted 26 November 2019

Inter-Personal Ties; Hon

\begin{abstract}
This study aims to analyze the implications of e-WoM components (intra-personal ties, homophile, credibility) on consumer purchasing decisions both directly and through mediating consumer preferences. Previous experience of consumer purchases conveyed by word of mouth can be a preference for other consumers in buying products or services. The development of digital communication makes electronic Word of Mouth (e-WoM) play an important role in influencing consumer preferences, especially for those who have to make purchasing decisions for products with many features such as gadgets. A total of 300 questionnaires were distributed around Jakarta using simple random sampling and obtained 102 complete responses from respondents. Data analysis was performed using descriptive statistical methods, correlational and multiple regression with the help of SPSS software. The results showed that the gadget purchase decision was partially influenced by consumer purchasing preferences and credibility sources, but this purchase preference was not as dominant as the credibility source. Gadgets are designed unusual and have many advanced technological features compared to conventional products, therefore the results of this study may not be valid for products outside of the gadget. Further research is needed whether eWoM has the same influence on consumer purchasing decisions of conventional products.
\end{abstract}

\section{Pengaruh Komunikasi e-WoM terhadap Preferensi Konsumen dan Keputusan Pembelian pada Gadget Elektronik}

\begin{abstract}
Abstrak
Penelitian ini bertujuan untuk menganalisis implikasi komponen e-WoM (ikatan intra-personal, homofili, kredibilitas) terhadap keputusan pembelian konsumen baik secara langsung maupun melalui mediasi preferensi konsumen. Pengalaman pembelian konsumen terdahulu yang disampaikan dari mulut ke mulut, bisa menjadi preferensi bagi konsumen lain dalam membeli produk atau jasa. Perkembangan komunikasi digital menjadikan electronic Word of Mouth (e-WoM) berperan penting dalam mempengaruhi preferensi konsumen terutama bagi mereka yang harus membuat keputusan pembelian produk dengan banyak fitur seperti gadget. Sebanyak 300 kuisioner disebarkan di sekitar Jakarta dengan menggunakan simple random sampling dan didapatkan 102 respon lengkap dari responden. Analisis data dilakukan dengan menggunakan metode statistik deskriptif, korelasional dan multi regresi dengan bantuan perangkat lunak SPSS. Hasil penelitian menunjukkan bahwa keputusan pembelian gadget secara parsial dipengaruhi oleh preferensi pembelian konsumen dan sumber kredibiltas, tetapi preferensi pembelian ini ternyata tidak terlalu dominan pengaruhnya dibandingkan sumber kredibiltas. Gadget memang dirancang tidak biasa dan memiliki banyak fitur teknologi canggih dibanding produk konvensional, oleh karenanya hasil penelitian ini mungkin tidak valid untuk produk-produk di luar gadget. Diperlukan penelitian lebih lanjut apakah e-WoM mempunyai pengaruh yang sama terhadap keputusan pembelian konsumen produk-produk konvensional.
\end{abstract}

JEL Classification: M3; M31

How to Cite: Hardjono, B., Riyadi, S.A., \& Aris, D. (2020). The Implication of e-Wom Communication on Customer Preference and Purchase Decision of Electronic Gadgets. Jurnal Dinamika Manajemen, 11(1), 1-11. 


\section{INTRODUCTION}

Deciding to buy a new product with a lot of technology features is not a simple matter. Gadget is one example of a product that has these characteristics. Gadgets are small technology items, which are considered as devices or appliances which have certain functions. The gadgets are also often regarded as a product that has a novelty (Valacich et al., 2018) .

Consumers often face problems if they want to buy a gadget. This is caused by their lack of understanding of the various features offered since the product contains some new technology. For example, someone who wants to buy a gadget in the form of a smartphone, often faced with so many features that must be chosen such as built quality, processor speed, display quality, camera reliability, battery endurance, user interface, storage capacity, security system, audio/speaker quality and many others. In this situation, consumers tend to rely on information from consumers who have experience with similar goods.

Consumers need purchasing preferences from previous consumers. In the world of digital communication, such preferences can easily be found through various social media channels, one of which is in the form of the electronic World of Mouth (e-WoM). Referring to this purchase preference, consumers feel it will be easier in the decision-making process of purchasing a gadget. Some special features of e-WoM include its form as a written and electronic communication, the possibility of its spread is very quickly, the reach is unlimited, observable and most are anonymous (Gfrerer \& Pokrywka, 2012). How eWOM influences the formation of a purchasing preference is largely determined by the role of its components. These components are interpersonal ties, homophiles, and sources of credibility.

In the WEB 2.0 world, word of mouth has been playing a more important role than ever before in influencing consumer decisions (Majláth, 2013). The opinions of others, especially the opinions of reference persons and groups, have always played a significant role in these decisions.
In a recent report on Global Trust in Advertising 2015, AC Nielsen also explained that the influence of WoM in advertising is significant. They stated that offline and online WOM communication is the top one (84\%) and third (66\%) There are most trusted forms of advertising in the world. $84 \%$ of global consumers trust in the recommendations from people they know which become the most trustworthy sources of information about products, while $66 \%$ of the global consumers trust the opinion posted online from experienced consumers. How e-WoM can now be widely spread and the factors that support it. The emergence of e-WoM is supported by the advancement of internet technology, extensive diffusion of social media applications and popularity of e-commerce (Ismagilova et al., 2017). The internet provides a diverse place so consumers can share their experiences, views, opinions, and preferences with others. The easier a potential buyer can access the internet, the more of them to use this e-WoM to get the preference of products they want to purchase.

There have been many studies on how purchasing preferences are formed by consumers both online and online. Likewise, how consumer preferences affect the purchase decision of a product. However, studies that have analyzed how e-Wom components affect purchasing decisions for products with many new technological features (gadgets), have not been widely publicized. Therefore the research novelty of this study is more directed to the analysis of the effect of e-WoM components on the purchase decision of customers through the purchase preferences as a mediator. In more detail, the influence of internal ties, homophiles, and source of credibility on customer purchase preferences will be analyzed, as well as how the purchasing decision of gadget products was affected by customer preferences (as a mediator) and the component credibility component.

\section{Hypothesis Development \\ The Relationship Customer Preference to- ward Interpersonal Ties}

The Word-of-mouth (WOM) is one of the most important information sources when a con- 
sumer is making a purchase decision (Yayli et al., 2012). There are a lot of definition of Electronic Word of Mouth in the academic paper but one of the good definition was given by Hennig-Thurau et al. (2004) that mentioned e-WoM as any positive or negative statement made by potential, actual, or former customers about a product or company, which is made available to a multitude of people and institutions via the Internet. Moreover, e-WOM also includes opinions and share of information not only about products but also about services and brands (Jalilvand et al., 2011).

Customer preference exists because of the underlying of demand. It's a model of how the consumer behaves. The individual consumer has a set of preferences and values that's determination is outside the realm of economics. Consumer preferences are defined as the subjective (individual) tastes, as measured by the utility, of various bundles of goods. In the context of product selection, consumer preference formation may include selecting a certain channel, a certain retailer, a certain product feature, and a certain service level (Voicu, 2013). The formation of customer preference can be explained as depicted in Figure 1. This explanation based on the theory of rational choice within different stages of the purchasing process.

All stages in the green shade are the components that form the customer preference. All of these components are now easier to be obtained from internet media through e-WoM instead of looking for them through the real experience of a customer through offline. This means e-WoM will play an important role in the formation of a customer preference.

Interpersonal ties are defined as the connections of information conveyed and transferred between the people. Generally, interpersonal ties distribute into three varieties including strong, weak or absent. If the interpersonal ties are strong, the social relationship so intense or even in the level of overlap within the friendship (Saleem \& Ellahi, 2017). Strong primary ties are referring to those with family members and relatives as well as close friends while weak secondary ties are those with acquaintances who rarely seen and lastly non-existent ties which are strangers.

$\mathrm{H} 1$ : Customer preference for the gadget is significantly influenced by interpersonal ties.

\section{The Relationship Customer Preference to- ward Homophily}

Other researchers also defined this eWoM as the communications through internetbased technology by consumers in an informal form about the experiences and characteristics of products and services as well as the sellers (Litvin et al., 2008). From these definitions, it can be synthesized that e-WoM is talking about electronic communication via the internet which contains any statements or experiences and cha-

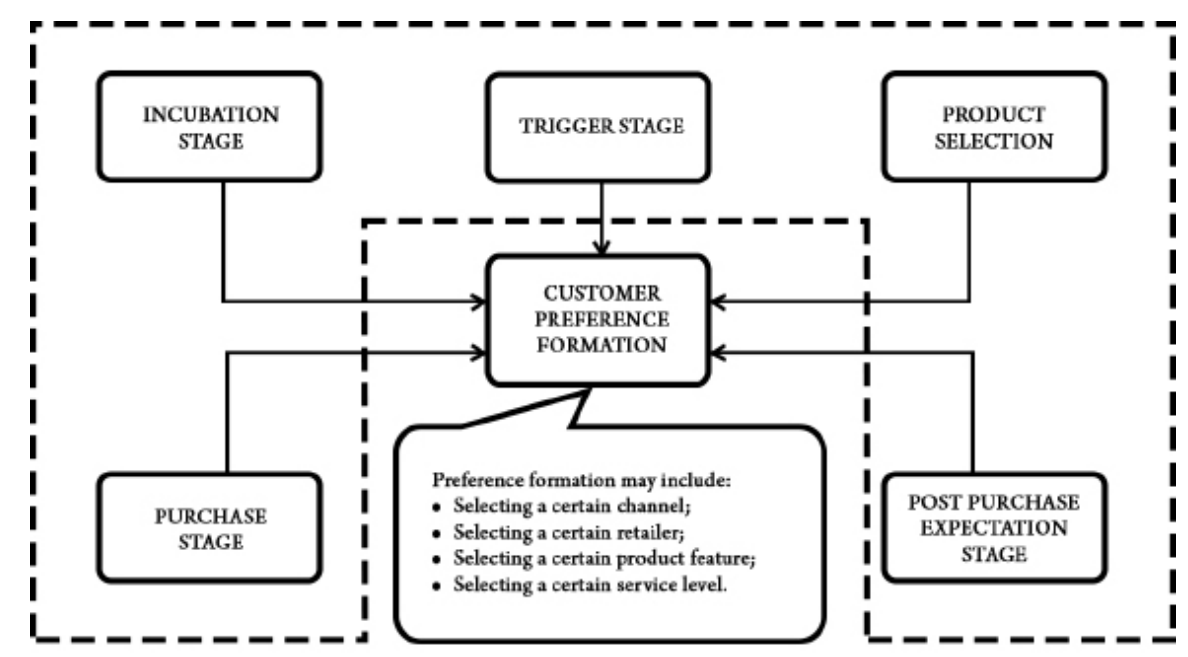

Figure 1. Evaluating the Purchasing Experience-Using the Model of Rational Choice within Different Stages of the Purchasing (Voicu, 2013). 
racteristics of products and services made by potential, actual or former customers. These experiences and characteristics are the customer preferences given by previous customers to potential customers through the internet.

Homophily is a degree to which individuals share the same characteristics as age, gender, education, and income, to the extent to which individuals communicate when they have common characteristics. The consumer who share a high level of homophily, will participate more in e-WOM with each other which ultimately shapes their purchase decisions (Chu \& Kim, 2011). The relationships with similar others provide positive reinforcement (Morry, 2005). Before that, The people make a decision on the characteristics of the message provider, if the reader finds that person is somehow like him, then the message becomes more persuasive to the reader (Petty \& Cacioppo, 1981). Furtherly in the quite recent study, Phua et al. (2017) found that for social networking sites (SNS) homophily, users who saw their SNS network as being more heterogeneous (low homophily) increased their bridging social capital, but decreased their bonding social capital with increased SNS use. Information from homophilous sources is preferred as compared to heterophilous, and information from homophilous is more influential in making consumer decisions (Saleem \& Ellahi, 2017). Homophily on electronic word of mouth communication has a significant impact in the context of social media and virtual marketing (Okazaki et al., 2017).

$\mathrm{H} 2$ : Customer preference of gadget is significantly influenced by homophily.

\section{The Relationship Customer Preference to- ward Sources of Credibility}

The strong e-WoM possibly will form a better preference to the potential customer. The determinant of consumer engagement in e-WoM was influenced by tie strength, homophily, trust, normative influence and informational influence (Chu \& Kim, 2011). The strength of e-WoM relies on the dimensions such as ties interpersonal, homophily, source of credibility, normative influence, and interpersonal influence (Bearden et al.,
1989; Saleem \& Ellahi, 2017). Another researcher (Oroh, 2014) argued that only three dimensions that will determine the strength of e-WoM which are ties strength, homophily. and source of credibility. Synthesizing all the above explanations, the customer preference possibly is formed by strong e-WoM through its dimension such as ties interpersonal, homophily, source credibility.

In some academic papers source of credibility is also known as trustworthiness, which is a message source's perceived ability (expertise) or motivation to provide accurate and truthful information. The source credibility as a theory identifies source expertise and source bias as elements that affect the credibility of an information source (Buda \& Zhang, 2008; Cheung \& Thadani 2010).

Consumers fall in difficulty in evaluating the quality of products as determining features and its effects becoming more complicated. Therefore, the availability of trustworthy WoM information for experience goods, including nearly all services, becomes critically important for consumers seeking to minimize risk in experience good consumption (Saleem \& Ellahi, 2017). The credibility of the source is essential for the message's effectiveness and is dependent on the message receiver's assessment of the sender's level of expertise, lack of bias and trustworthiness (Kiecker \& Cowles, 2002). If the source has credibility, consumers will believe the message. Message source credibility is a high-order construct consisting of two sub-dimensions which are trustworthiness and expertness (Wu \& Wang, 2011).

H3: Customer preference of gadget is significantly and partially influenced by the sources of credibility.

\section{The Relationship Customer Preference to- ward Purchase Decision}

The purchase decision is the thought process that leads a consumer from identifying a need, searching information, generating options, choosing a specific product and brand, to evaluating the post-purchase (Huang \& Benyoucef, 2017). These five process stages first introduced by John Dewey in 1910. If the five 
stages have been completed by the customer, then the next cycle of the five stages becomes the process of forming purchase preferences which are a reference for other customers especially those who want to buy products that are not fully understood by all of its features. In the era of digital communications, this information is very easy to be found in the internet world through e-WoM or another communication channel. The more major the purchase decision, the more effort is typically put into the process. There are three factors influencing e-WOM that affect the consumer buying decision (Park et al., 2011). One of the factors is the experience of eWOM. The individuals who make online shopping by referring frequently to the online reviews are more willing to use and spread online review. So, before potential customers go to the final purchase decision, they try to get a preference via e-WoM. Since gadget products usually have a high price due to its novelty, they need more major purchase decisions, consequently the more customer preference before they come to the final decision to buy it.

$\mathrm{H} 4$ : Customer purchase decision of gadget is significantly influenced by customer preference.

\section{The Relationship Customer Preference to- ward Customer Purchase Decision, Interper- sonal Ties and Source of Credibility}

Electronic word of mouth from interpersonal ties which consist of close friend, family or person who could give advice or have influence on consumer purchasing decision (Wang et al., 2018). The mechanism how interpersonal ties work depends on strong or weak influence. Strong interpersonal ties will affect greater influence on purchase decision, and vice versa.
Another person is associated with source of information when consumer will purchase good or service. Group reference have significant impact to influence consumer purchase decision because they are believed have important testimoni (Huang \& Benyoucef, 2017). Consumer trust to their group reference if they have experience relate to product usage. Electronic word of mouth playing fabulous impact, because it used by consumer when looking for information (Kim et al., 2018). Consumer have limited information, therefore internet is the answer. Hence, when consumer browse for products, they are not barely trust on the promotion, it depend on who convince that product is suitable (Djafarova \& Trofimenko, 2019). Celebrity endorser, close friend or person who admired by consumer is the central actor who create trust, therefore consumer confident to buy product (Zhu et al., 2016; Djafarova \& Rushworth, 2017; Tien et al., 2019). To conclude, interpersonal ties not directly affect customer purchase decision, hence it depends on source of credibility. Because the source of credibility is also expected to influence partially on purchasing decisions, the hypothesis can be written as follows: H5: Customer purchase decision of gadget partially influenced by interpersonal ties through a source of credibility.

\section{Research Framework}

By combining the rational choice model and the stages before the purchase decision, a theoretical framework can be derived which illustrates the causal relationship between eWoM components with the purchase decision through mediating consumer purchasing preferences as shown in Figure 2.

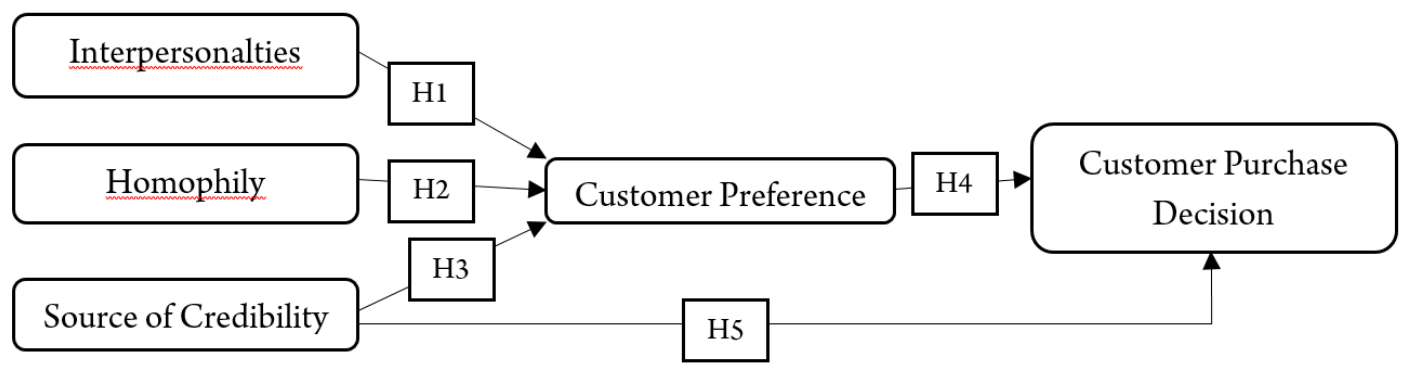

Figure 2. Research Framework 
From Figure 2, some hypotheses could be derived and proven whether the dependent variables are significantly affected by its predictors. For the first step, the hypothesis will be derived from the components of e-WoM toward customer preference as its dependent variable.

\section{METHOD}

This study used a quantitative methodology while it was designed by using explanatory research since most of the discussion on findings was based on established and well-known theory. Research is focused to examine the relationship between variables of e-WoM components, (interpersonal ties, homophily, and source of credibility) indirectly towards customer purchase decisions through customer preference while the direct influence of source credibility will be investigated as well to the customer purchase decisions.

The questionnaire was used as a research instrument in which variables to be questioned were set up based on three-factor dimensions in e-WoM such as interpersonal, homophily and source of credibility.

\section{Sampling and Analysis Tools}

Non-probability purposive sampling technique was used for this study based on the experience from previous research. Target respondents were set up for the people/customer who stays in the Great Jakarta City and its satellite since these cities are modern enough and the people familiar in using the gadget products. Other criteria for these respondents are they must be educated people (from secondary school students to master/ doctorate level education), can be female or male, familiar and frequently using internet and a gadget in daily life.

Among 300 questionnaires were distributed electronically by using the Google form, and about 102 completed questionnaires can be collected and analyzed. Likert scale with the range 1-5 was applied in the questionnaire so respondents can assess every question they answered.

All data collected from the respondents we analyzed with the help of the SPSS software system by using statistical tools such as crosstabulation (for descriptive analysis), correlational analysis and multiple regression analysis to find out how far the relationship between independent and dependent variables in this study.

\section{RESULT AND DISCUSSION}

\section{Demographic Profile of Respondents}

From 300 questionnaires distributed, only 102 respondents answered in full the requested data. The profile of the respondents are as Table1.

From Table 1, it can be seen that the dominance of respondents is more towards women, whereas based on profession, respondents are dominated by professional circles followed by academicians and business owners. Most of these respondents (56\%) turned out to use more

Tabel 1. Demographic Profile of Respondent

\begin{tabular}{lcc}
\hline \multicolumn{1}{c}{ DESCRIPTION } & TOTAL & \% \\
\hline Respondent by Gender & & \\
Female & 57 & $56 \%$ \\
Male & 45 & $44 \%$ \\
Respondent by Profession & & \\
Professional & 25 & $32 \%$ \\
Academician & 26 & $25 \%$ \\
Business Owner & 26 & $25 \%$ \\
Students & 8 & $8 \%$ \\
Others & 17 & $17 \%$ \\
Respondent by Education & & \\
Ph.D & 8 & $8 \%$ \\
Master & 40 & $39 \%$ \\
Bachlor/Diploma & 44 & $43 \%$ \\
Sr. High School & 9 & $9 \%$ \\
Others & 1 & $1 \%$ \\
Respondent by the Time & & \\
Consumed for Internet & & \\
1 Hour & 5 & $5 \%$ \\
1-2 Hour & 12 & $12 \%$ \\
3-4 Hour & 27 & $27 \%$ \\
$>4$ Hour & 56 & $56 \%$ \\
Respondent by Characteristic & & \\
of Gadget Used & & \\
Fanatic & 23 & $23 \%$ \\
Active User & 65 & $64 \%$ \\
Ordinary User & 14 & $14 \%$ \\
Not a User & 0 & $0 \%$ \\
\hline
\end{tabular}


Budiono Hardjono, et al./ The Implication of e-WoM Communication on ...

than 4 hours a day to connect to the internet and $64 \%$ of the total respondents were active users of gadget devices. By combining profession data and the gadget use in Figure 3, the most active gadget users are from the business owner group followed by academics and others. The fanatical gadget users come from academicians. This shows that the serious enthusiasts of this gadget are indeed from businessmen and academics. It can be predicted that this gadget is indeed a supporting useful tool for their performance. Especially for the business owner, the use of gadgets become so important to increase their productivity.

\section{Correlational Analysis}

Alpha Pearson's number indicates how strong the correlation between the dependent variable with its predictors. The result for all of the variables is shown in Table 2.

Alpha Person numbers of e-Wom components (interpersonal ties, homophily, and source of credibility) to the customer preference respectively are $0.315,0.208$, and 0.486 . This means that the strongest relationship between the e-Wom components and customer preference is the source of credibility, followed by interpersonal ties and homophiles. Although the value varies but all

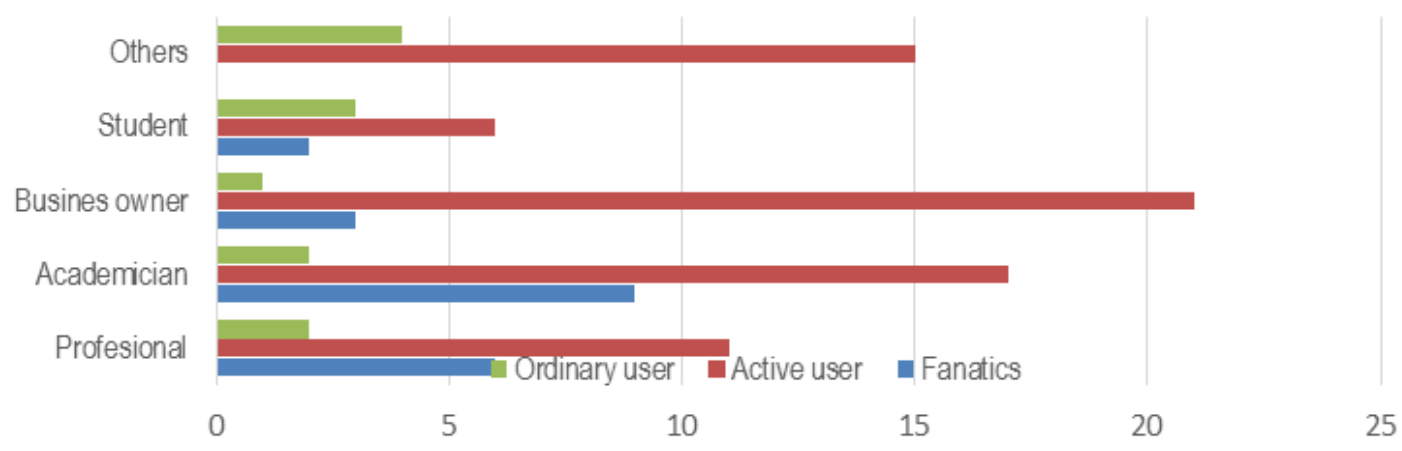

Figure 3. The Typical Charactheristic of Gadget Users by Profession.

Table 2. Pearson Correlation

\begin{tabular}{llccccc}
\hline & & ITav & Hmav & SCav & CPav & PDav \\
\hline \multirow{3}{*}{ ITav } & Pearson Correlation & 1 & $.423^{* *}$ & $.292^{* *}$ & $.315^{* *}$ & $.382^{* *}$ \\
& Sig. (2-tailed) & & 0 & .003 & .001 & 0 \\
& $\mathrm{~N}$ & & 102 & 102 & 102 & 102 \\
& Pearson Correlation & & 1 & $.211^{* *}$ & $.208^{* *}$ & $.475^{* *}$ \\
HMav & Sig. (2-tailed) & & .002 & .003 & 0 \\
& $\mathrm{~N}$ & & 102 & 102 & 102 \\
& Pearson Correlation & & 1 & $.486^{* *}$ & $.264^{* *}$ \\
SCav & Sig. (2-tailed) & & & 0 & 0 \\
& $\mathrm{~N}$ & & & 102 & 102 \\
& Pearson Correlation & & & & $.207^{* *}$ \\
CPav & Sig. (2-tailed) & & & & .003 \\
& $\mathrm{~N}$ & & & & 102 \\
& Pearson Correlation & & & & 1 \\
PDav & Sig. (2-tailed) & & & & \\
& $\mathrm{N}$ & & & & & \\
\hline
\end{tabular}

**. Correlation is significant at the 0.01 level (2-tailed).

Note: ITav : Interpersonal Ties, HMav : Homophily, SCav : Source of credibility, CPav : Customer Preference, PDav : Purchase Decision 
Table 3. Result on First Regression for The Model

\begin{tabular}{ccccc}
\hline Model & R & R Square & Adjusted R Square & Std. Error of the Estimate \\
\hline 1 & $.809^{\mathrm{a}}$ & .655 & .644 & .52984 \\
\hline
\end{tabular}

Table 4. Coefficient Regression for First Step

Coefficients $^{\mathrm{a}}$

\begin{tabular}{lcccccc}
\hline \multirow{2}{*}{ Model } & \multicolumn{2}{c}{ Unstandardized Coefficients } & Standardized Coefficients & \multirow{2}{*}{ t } & \multirow{2}{*}{ Sig. } \\
\cline { 2 - 4 } & $\mathbf{B}$ & Std. Error & Beta & & .045 & .964 \\
\cline { 1 - 2 } (Constant) & .015 & .342 & & .724 & .471 \\
ITav & .057 & .078 & .049 & 9.460 & .000 \\
HMav & .806 & .085 & .703 & .134 & .035 \\
SCav & .205 & .096 & .146 & 2.134 \\
\hline
\end{tabular}

of these correlations are significant enough since the $\alpha$ value $<0.05$. From the correlation between customer preferences and customer purchase decisions, it appears that although the correlation between the two is not too dominant (Pearson value: 0.203 ), it is quite significant.

\section{Regression Analysis}

Referred to the theoretical framework, a mediating variable was used before arriving at the final result, therefore some steps of regression should be done. Firstly, regression is done between dependent variable customer preference $(\mathrm{PR})$ and its predictors (interpersonal ties, homophily, and source of credibility. The results are shown in Table 3 and Table 4.

These results indicate that the change in customer preference can be explained by $65.5 \%$ from its predictors as indicated by the value of $\mathrm{R}$-squared. But in the table coefficient, variable
IT (interpersonal ties) is not significant enough due to alpha more than 0.05 .

Therefore $\mathrm{H} 1$ is rejected and the hypothesis can be concluded as follow:

$\mathrm{H} 1$ : Customer preference of gadget is not influenced by interpersonal ties.

$\mathrm{H} 2$ : Customer preference of gadget is influenced by homophily.

H3: Customer purchase preference of gadget is influenced partially by the source of credibility.

The second regression is done between variable purchase decision and its predictor, consumer preference. These results are shown in Table 5 and Table 6.

As mentioned in the first regression, the predictors that affect the customer preference are homophily and the source of credibility, while interpersonal ties are not significant. When

Table 5. Model Summary for Regression Step 2

\begin{tabular}{ccccc}
\hline Model & R & R Square & Adjusted R Square & Std. Error of the Estimate \\
\hline 1 & $.380^{\mathrm{a}}$ & .144 & .136 & .66611 \\
\hline
\end{tabular}

Table 6. Coefficient Regression of Customer Preference in Step 2

\begin{tabular}{cccccccc}
\hline \multirow{2}{*}{ Model } & \multicolumn{2}{c}{ Unstandardized Coefficients } & Standardized Coefficients & \multirow{2}{*}{ t } & \multirow{2}{*}{ Sig. } \\
\cline { 3 - 5 } & $\mathbf{B}$ & Std. Error & Beta & 9.534 & .000 \\
\multirow{2}{*}{1} & (Constant) & 2.634 & .276 & & .380 & 4.106 & .000 \\
\hline & CPav & .303 & .074 & &
\end{tabular}


Budiono Hardjono, et al./ The Implication of e-WoM Communication on ...

the second regression has proceeded between customer purchase decision and its predictor (customer preference), it is proven that this predictor affects the customer purchase decision, but the effect is not as strong as indicated by the value of the $\mathrm{R}$-Square which is only 0.144 . This means only $14.4 \%$ of the change independent variable can be explained by the change of its predictor. Nevertheless, it can be stated for the hypothesis as follow:

H4: Customer purchase decision of a gadget is influenced by customer preference.

Although customer preference is still considered by potential customer, for the purchase of gadget product customers tend to find out another reference which stronger than the customer preference.

Lastly, the regression process is conducted to the source of credibility as a predictor towards customer purchase decisions as a dependent variable. The results are shown in Table 7 and Table 8.

Table 7. Model Summary for Regression Step 3

\begin{tabular}{ccccc}
\hline Model & R & $\begin{array}{c}\text { R } \\
\text { Square }\end{array}$ & $\begin{array}{c}\text { Adjusted R } \\
\text { Square }\end{array}$ & $\begin{array}{c}\text { Std. Error of } \\
\text { the Estimate }\end{array}$ \\
\hline 1 & $.880^{\mathrm{a}}$ & .774 & .772 & .34201 \\
\hline
\end{tabular}

As one of the predictors, customer preference is affected by the source of credibility, but this source of credibility also goes to the customer purchase decision (partially). The influence of customer preference toward customer purchase decision is not strong as indicated by its R-square value (0.144), but as a predictor of the customer purchase decision; the source of credibility has a quite strong effect. The source of credibility is significant and the $\mathrm{R}$-square value is 0.774 . This is very good to explain that the change in the customer purchase decision is really can be described by $77.4 \%$ of the changes in its predictor. Therefore the hypothesis can be stated as:

H5: Customer purchase decision of gadget are partially influenced by customer preference and source of credibility.
Table 8. Coefficient Source Credibility for Regression Step3

\begin{tabular}{|c|c|c|c|c|c|}
\hline \multirow{2}{*}{ Model } & \multicolumn{3}{|c|}{$\begin{array}{c}\text { Unstandardized Standardized } \\
\text { Coefficients Coefficients }\end{array}$} & \multirow{2}{*}{ t } & \multirow{2}{*}{ Sig. } \\
\hline & B & $\begin{array}{l}\text { Std. } \\
\text { Error }\end{array}$ & Beta & & \\
\hline 1 (Constant) & -.043 & .208 & & -.207 & .836 \\
\hline SCav & .994 & .054 & .880 & 18.418 & .000 \\
\hline
\end{tabular}

This discussion can lead to the character tendency of the potential buyers of gadgets. The $\mathrm{R}$-square value of customer preference (0.144) is less than the R-square value of the source of credibility (0.774). This indicates that the customers are not depending on the customer preference but tend to more believe in the source of credibility as a purchase reference. Maybe this is because of the characteristic of the gadget and its users. The gadget is mostly a newly developed product which a lot of novelty there, even many people don't know about the detail of the features. The development is very fast and not easy to catch up and therefore maybe also not easy to find out the credible review in the e-WoM. People possibly tend to depend on the expertise of some people who are credible in providing some information about new gadget products.

\section{CONCLUSION AND RECOMMENDATION}

In this research, it is proven that homophily and source of credibility have an effect on the formation of customer preference, but unfortunately, this customer preference is not really to become considerations for the potential customers when they want to buy gadget products. Statistically, the change in the customers' purchase decision can be explained by $14.4 \%$ by the changes in their predictor, meaning this is not good to rely on the customer preference when customers need to buy a gadget. On the other hand, $77.4 \%$ of the change in customer purchase decisions can be explained from the change of the source of credibility. Consequently, this leads customers to choose the source of credibility for their reference to purchase a gadget. 
The characteristic of gadgets which have many new things in technology, the novelty, and other features, make some customers not easy to find out the very up to date information about the products. This is similar to other electronic products that very fast to change every time. Source of credibility gives the customers some experiences and expertise about the technology or other features in the gadget and they can get it all through e-WoM.

From the respondent, many of them categorized as active gadget users or even very fanatics on it. They always try to find out the latest development to whatever gadget they are interested in. For people like them, the source of credibility is very important. The speed to have information and the quality of recommendation from the expert is very important.

To conclude this entire study, although customer purchase decisions of a gadget is influenced partially by both customer preference and source of credibility, the customer tends to choose the source of credibility in buying the gadget products. The characteristics of the gadget are very easy to change and develop. This makes potential buyers need faster information directly from the experts in this field who can be sought through e-WoM from various digital communication channels.

This study discusses how gadget purchasing decisions are influenced by several components of e-WoM. As explained earlier that a gadget is an item that has a novelty and tends to require referrals when consumers want to buy it. Because the research only discusses concerning gadgets, the results of the research may not necessarily apply to other types of products. A separate study is needed to investigate the impact of e-WoM components on other general products.

\section{REFERENCES}

Buda., \& Zhang. (2008). Consumer Product Evaluation: the Interactive Effect of Message Framing, Presentation Order, and Source Credibility. Journal of Product \& Brand Management, 9(4), 229-242.
Cheung, C. M., \& Thadani, D. R. (2012). The Impact of Electronic Word-of-Mouth Communication: a Literature Analysis and Integrative Model. Decision Support Systems, 54(1), 461-470.

Chu, S. C., \& Kim, Y. (2011). Determinants of Consumer Engagement in Electronic Word-ofMouth (eWOM) in Social Networking Sites. International journal of Advertising, 30(1), 4775.

Djafarova, E., \& Rushworth, C. (2017). Exploring the Credibility of Online Celebrities' Instagram Profiles in Influencing the Purchase Decisions of Young Female Users. Computers in Human Behavior, 68(March), 1-25.

Djafarova, E., \& Trofimenko, O. (2019). 'Instafamous'-Credibility and Self-Presentation of Micro-Celebrities on Social Media. Information, Communication \& Society, 22(10), 14321446.

Gfrerer, A., \& Pokrywka, J. (2012). Traditional vs. Electronic Word-of-Mouth: a Study of WOM Communication and Its Influence on Young Consumers Within the Automobile Industry. Thesis. International Marketting and Brand Management. Lund University.

Hennig-Thurau, T., Gwinner, K. P., Walsh, G., \& Gremler, D. D. (2004). Electronic Word-ofMouth via Consumer-Opinion Platforms: What Motivates Consumers to Articulate themselves on the Internet?. Journal of Interactive Marketing, 18(1), 38-52.

Huang, Z., \& Benyoucef, M. (2017). The Effects of Social Commerce Design on Consumer Purchase Decision-Making: an Empirical Study. Electronic Commerce Research and Applications, 25(September-October), 40-58.

Ismagilova, E., Dwivedi, Y. K., Slade, E., \& Williams, M. D. (2017). Electronic Word of Mouth (eWOM) in the Marketing Context: a State of the Art Analysis and Future Directions. Wales: Springer.

Jalilvand, M. R., Esfahani, S. S., \& Samiei, N. (2011). Electronic Word-of-Mouth: Challenges and Opportunities. Procedia Computer Science, 3(October), 42-46.

Kiecker, P., \& Cowles, D. (2002). Interpersonal Communication and Personal Influence on the Internet: a Framework for Examining Online Word-of-Mouth. Journal of Euromarketing, 11(2), 71-88.

Kim, S., Kandampully, J., \& Bilgihan, A. (2018). The Influence of eWOM Communications: 
Budiono Hardjono, et al./ The Implication of e-WoM Communication on ...

an Application of Online Social Network Framework. Computers in Human Behavior, 80(March), 243-254.

Litvin, S. W., Goldsmith, R. E., \& Pan, B. (2008). Electronic Word-of-Mouth in Hospitality and Tourism Management. Tourism Management, 29(3), 458-468.

Majláth, M. (2013). Who does Generate e-WOM and Why? a Research Proposal. Acta Polytechnica Hungarica, 10(6), 135-150.

Morry, M. M. (2005). Relationship Satisfaction as a Predictor of Similarity Ratings: a Test of the Attraction-Similarity Hypothesis. Journal of Social and Personal Relationships, 22(4), 561-584.

Okazaki, S., Andreu, L., \& Campo, S. (2017). Knowledge Sharing among Tourists via Social Media: a Comparison between Facebook and TripAdvisor. International Journal of Tourism Research, 19(1), 107-119.

Oroh, W. L. (2014). The Influence of Consumers'tie Strength, Homophily and Source Credibility toward Electronic Word-of-Mouth (EWoM) Behavior. Jurnal EMBA: Jurnal Riset Ekonomi, Manajemen, Bisnis dan Akuntansi, 2(3).12141329.

Park, C., Wang, Y., Yao, Y., \& Kang, Y. R. (2011). Factors Influencing Ewom Effects: Using Experience, Credibility, and Susceptibility. International Journal of Social Science and Humanity, 1(1), 74-79.

Petty, R. E., Cacioppo, J. T., \& Goldman, R. (1981). Personal Involvement as a Determinant of Argument-Based Persuasion. Journal of Personality and Social Psychology, 41(5), 847-855.

Phua, J., Jin, S. V., \& Kim, J. J. (2017). Uses and Gratifications of Social Networking Sites for Bridging and Bonding Social Capital: a Comparison of Facebook, Twitter, Instagram, and Snapchat. Computers in Human Behavior, 72 (July), 115-122.
Saleem, A., \& Ellahi, A. (2017). Influence of Electronic Word of Mouth on Purchase Intention of Fashion Products on Social Networking Websites. Pakistan Journal of Commerce and Social Sciences, 11(2), 597-622.

Tien, D. H., Rivas, A. A. A., \& Liao, Y. K. (2019). Examining the Influence of Customer-to-Customer Electronic Word-of-Mouth on Purchase Intention in Social Networking Sites. Asia Pacific Management Review, 24(3), 238-249.

Valacich, J. S., Wang, X., \& Jessup, L. M. (2018). Did I Buy the Wrong Gadget? How the Evaluability of Technology Features Influences Technology Feature Preferences and Subsequent Product Choice. Management Information Systems Quarterly, 42(2), 633-644.

Voicu, M. C. (2013). Characteristics of the Consumer Preferences Research Process. Econ Papers, Global Economic Observer, 1(1), 126-134.

Wang, J. J., Wang, L. Y., \& Wang, M. M. (2018). Understanding the Effects of EWoM Social Ties on Purchase Intentions: a Moderated Mediation Investigation. Electronic Commerce Research and Applications, 28(March-April), 54-62.

Wu, P. C., \& Wang, Y. C. (2011). The Influences of Electronic Word-of-Mouth Message Appeal and Message Source Credibility on Brand Attitude. Asia Pacific Journal of Marketing and Logistics, 23(4), 448-472.

Yayli, A., \& Bayram, M. (2010). eWOM: The Effects of Online Consumer Reviews on Purchasing Decision of Electronic Goods. Proceedings. International Marketing Trends Conference Venice, 21-23 January 2010.

Zhu, D. H., Chang, Y. P., \& Luo, J. J. (2016). Understanding the Influence of C2C Communication on Purchase Decision in Online Communities from a Perspective of Information Adoption Model. Telematics and Informatics, 33(1), 8-16. 